\title{
Ilizarov external fixator for correction of complex foot deformities
}

\author{
İlizarov eksternal fiksatörü ile karmaşık ayak deformitelerinin düzeltilmesi
}

\author{
Osman Tecimel, M.D., ${ }^{1}$ D. Ali Öçgüder, M.D., ${ }^{1}$ Metin Doğan, M.D., ${ }^{2}$ Mahmut Uğurlu, M.D., ${ }^{2}$ \\ Murat Bozkurt, M.D., ${ }^{2}$ Sabri Ateşalp, M.D. ${ }^{3}$ \\ 'Department of Orthopedics and Traumatology, Atatürk Training and Research Hospital, Ankara, Turkey \\ ${ }^{2}$ Department of Orthopedics and Traumatology, Medicine Faculty of Yıldırım Beyazıt University, Ankara, Turkey \\ ${ }^{3}$ Department of Orthopedics and Traumatology, Gülhane Military Medical Academy, Ankara, Turkey
}

Objectives: This study aims to evaluate the outcomes of the Ilizarov external fixator for the correction of complex foot deformities.

Patients and methods: Between January 2000 and September 2005, 29 feet of 25 patients (18 males, 7 females; mean age 13.7 years; range 5 to 24 years) who were applied Ilizarov external fixators due to complex foot deformities in our clinic were prospectively analyzed. Four patients had bilateral foot deformity. The distribution of the deformities was as follows: hindfoot inversion (calcaneovarus) in 29 , forefoot equines (cavus) in 29, forefoot adductus in 28 , forefoot and hindfoot supination in 27 and forefoot and hindfoot pronation in one foot. The mean length of hospital stay was 9.4 weeks (range, 6 to 18 weeks). Osteotomy was required in nine patients with ages ranging from 13 to 24 . Middle subtalar osteotomy was applied on six patients, while three patients received subtalar osteotomy. In three patients, release was provided by removal of incision scar tissue. The mean follow-up was 48 months (range, 16-65 months).

Results: The mean treatment period was 21.6 weeks (range, 18-31 weeks). All patients walked better following treatment. According to Paley's criteria, 27 feet were evaluated as plantigrade (flat) and two as non-plantigrade (non-flat). Two patients suffered from pain. The success rate of the treatment was $86.2 \%$.

Conclusion: Ilizarov method appears to be an efficient approach thanks to the three dimensional characteristic of the foot and fixator in the correction of complicated foot deformities.

Key words: Foot deformity, Ilizarov external fixator, surgical treatment.
Amaç: Bu çalışmada karmaşık ayak deformitelerinin düzeltilmesinde İlizarov eksternal fiksatörünün sonuçları değerlendirildi.

Hastalar ve yöntemler: Ocak 2000 ile Eylül 2005 tarihleri arasında kliniğimizde karmaşık ayak deformitesi nedeniyle İlizarov eksternal fiksatörü uygulanan 25 hastanın (18 erkek, 7 kadın; ort. yaş 13.7 yıl; dağılım 5-24 yıl) 29 ayağı prospektif olarak değerlendirildi. Dört hastada iki taraflı ayak deformitesi vardı. Deformitelerin dağılımı şu şekildeydi: 29 ayakta arka ayak inversiyon (kalkaneovarus), 29 ayakta ön ayak ekin (cavus), 28 ayakta ön ayak adduksiyon, 27 ayakta ön ve arka ayak supinasyonu ve bir ayakta ön ve arka ayak pronasyonu vardı. Ortalama hastanede kalış süresi 9.4 hafta (dağılım, 6-18 hafta) idi. Yaşları 13-24 arası olan dokuz hastada osteotomi gereksinimi oldu. Altı hastada orta subtalar osteotomi uygulanırken, üç hastada subtalar osteotomi uygulandı. Üç hastada kesi yerindeki skar dokusunun çıkarılması ile gevşetme sağlandı. Ortalama takip süresi 48 ay (dağılım, 16-65 ay) idi.

Bulgular: Hastaların tedavi süresi ortalama 21.6 hafta (dağılım, 13-31 hafta) idi. Tüm hastalar tedaviden sonra daha iyi yürüdü. Paley kriterlerine göre, 27 ayak plantigrade (düz basma), iki ayak ise plantigrade olmayan (düz basamayan) olarak değerlendirildi. İki hastanın ağrısı vardı. Tedavinin başarı oranı $\% 86.2$ idi.

Sonuç: İlizarov yöntemi, karmaşık ayak deformitelerinin düzeltilmesinde, ayağın ve fiksatörün üç boyutlu özelliği sayesinde, etkili bir yaklaşım olarak görülmektedir.

Anahtar sözcükler: Ayak deformitesi, İlizarov eksternal fiksatör, cerrahi tedavi.

- Received: February 05, 2012 Accepted: April 03, 2013

- Correspondence: Ali Öçgüder, M.D. Ümit Mahallesi, 444. Sok., Kermes Sitesi 3. Blok, No: 27, 06580, Ankara, Turkey. Tel: +90 312 - 2912525 / 3856 Fax: +90 312 - 2912705 e-mail: aliocguder@yahoo.com 
Complex foot deformity can be defined as a multiplanar deformity which may present with foot shortening (Figure 1). The deformity may be accompanied by other chronic problems such as poor soft tissue coverage due to recurring or neglected cases, leg length discrepancies, lower leg deformities, osteomyelitis, and nonunions. Such deformities may occur as a result of trauma, poliomyelitis, osteomyelitis, burn contractures, neuromuscular diseases or may present as a resistant congenital contracture such as clubfoot. ${ }^{[1,2]}$

Although there are several modern treatment techniques for management of relapsing and neglected deformities, problems are common for persistent deformities and defective cases. ${ }^{[1-11]}$ Abnormally tight ligaments and tendons hinder further growth and result in complicated deformities. ${ }^{[1-5,6-13]}$

The Ilizarov fixator, a new and more efficient method in the treatment of orthopedic foot problems, is capable of altering the form and dimensions of the bones through proper application of loads (compression and distraction) on various parts of the foot. It may also correct the components of the deformities by combining a number of functional units (uniplanar or multiplanar hinges and traction equipment), enabling the treatment of infantile, adolescent and adult patient

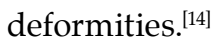

\section{PATIENTS AND METHODS}

Twenty-nine foot deformities of 25 patients (18 males, 7 females; mean age 13.7 years; range 5 to 24 years) who received correction by Ilizarov external fixator between January 2000 and September 2005 were evaluated prospectively. All the deformities except one were congenital. In 26 of the 29 feet corrected by Ilizarov method, the deformities were related to primary postoperative residual pes equinovarus. Two patients had an idiopathic and one had spastic paralysis

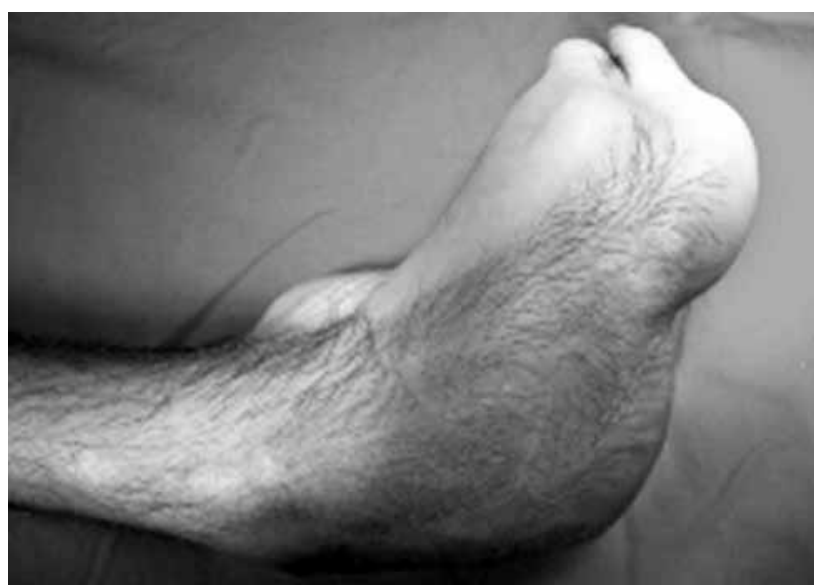

Figure 1. Dorsal and medial views of the foot preoperatively. induced pes cavovarus. Correction was made on three of the 26 residual pes equinovarus feet. Twenty-one left and eight right feet underwent correction with Ilizarov external fixator.

The analysis of the deformities in the patients revealed that 29 feet had hindfoot inversions (calcaneovarus), 29 feet had forefoot equines (cavus), 28 feet had forefoot adductus, 27 feet had forefoot and hindfoot supination and one foot had forefoot and hindfoot pronation. All the patients were hospitalized during the deformity correction for an average of 9.4 weeks (range, 6 to 18 weeks).

Osteotomy was needed in nine patients with ages ranging from 13 to 24 . Middle subtalar osteotomy was applied in six patients while three patients received subtalar osteotomy. Correction was aided by removing a wedge of 20 degree in one patient. Frames were applied after osteotomy in all patients. Tibial corticotomy was performed in two patients because of limb length discrepancy. Lengthening was started after 7.8 postoperative days (range; 5 to 11 days) at a speed of $4 \times 0.25 \mathrm{~mm} /$ day simultaneous with the deformity correction.

\section{Frame design}

Ilizarov fixation frames generally consisted of two full rings in tibia, two half rings in calcaneus and forefoot (Figure 2). The full ring at the distal tibia was fixed by three rods to half ring of calcaneus at medial, lateral and posterior projections. Ankle motion was provided during the correction phase by placing hinges at appropriate directions to the calcaneal ends of the rods.

The half ring at the level of the hindfoot was fixed to the calcaneus by olived Kirschner wires (K-wires) with the olives being respectively placed medial and lateral. The half rings at the end of the

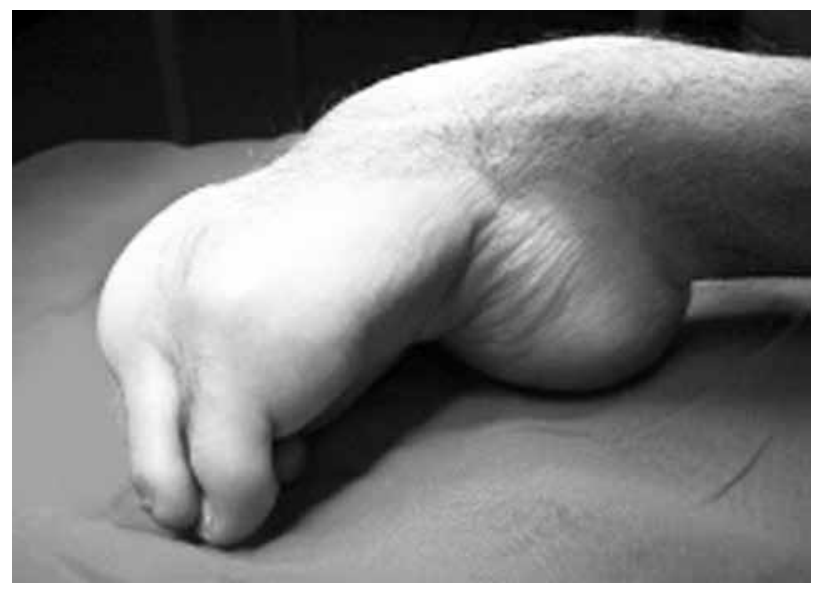



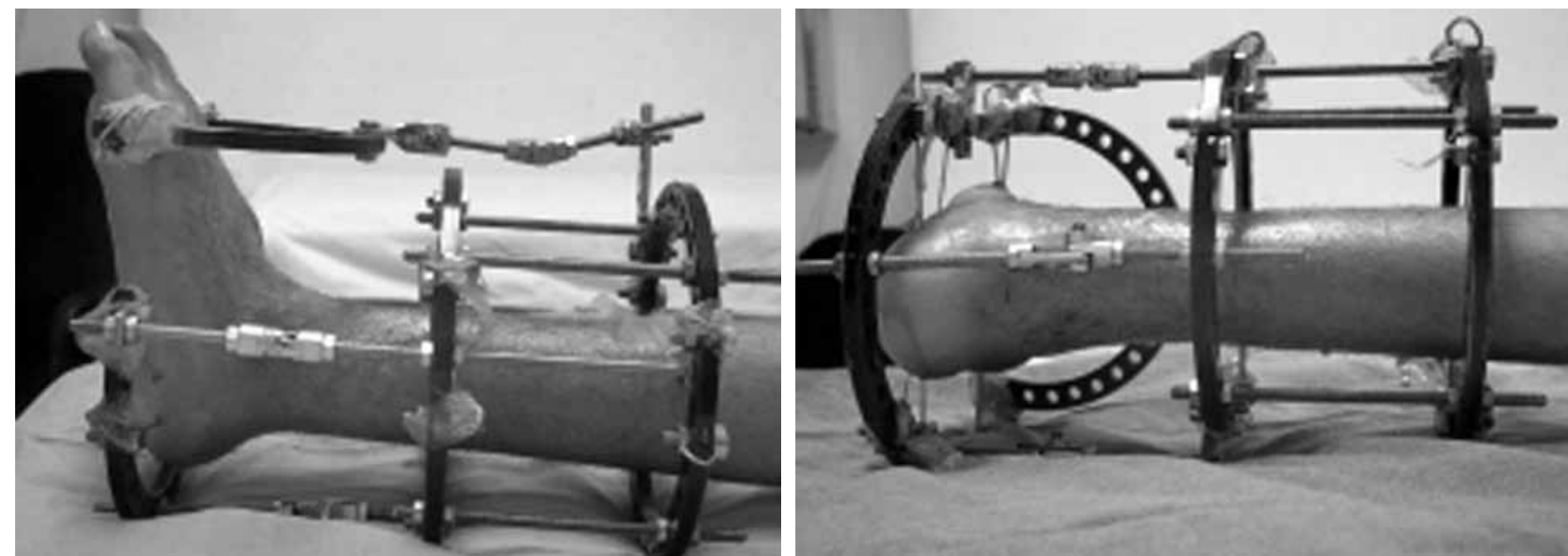

Figure 2. Correction of the foot by llizarov fixator (medial and posterior view).

forefoot were connected to each other with rods equipped with one and two-plane hinges to achieve movement in both sagittal and coronal planes. The medial rod was elongated to overcome metatarsus adductus deformity, and where an elongation of the foot was needed, the lateral rod was extended somewhat less than the medial. Although a certain amount of correction was obtained through this elongation, the main correction was achieved by shortening the anterior rod between the metatarsal half ring and the tibial ring, whereby the forefoot or entire foot equinus was corrected. The paramedian placement of the anterior rod allowed the correction of supination and pronation deformities.

\section{Aftercare}

Correction of the deformity was started immediately after relief of pain and edema on the foot. In two patients, the neurovascular status of the feet were found to be at risk due to excessive deformity correction, thus the correction was resumed after a few days of rest with a modification on the frame.

Physiotherapists instructed the patients during their hospitalization about the range of motion and muscular strengthening exercises. All the patients were discharged after completion of deformity exercises. The average time in which the feet remained in the frames was 15 weeks (range; 13 to 18 weeks). The feet of all the patients were then placed in cast under forced deformity correction for an average period of 6.7 weeks (range; 5 to 8 weeks), and they were followed up after prescribing suitable boots. The results were evaluated according to Paley's criteria, ${ }^{[8]}$ under which the gait was assessed as worse, unchanged or better. The foot deformity was evaluated as plantigrade or non-plantigrade, painful or painless, and if the pain continued, as better or worse. The treatment was considered as successful if the gait was better, foot was plantigrade and painless.

Major complications were listed as malunion which required additional surgery, heterotropic ossification, arthrosis, and nerve paralysis while minor complications included pin tract infections that did not cause any sequelae.

The average follow-up time was 48 months (range; 16 to 65 months) from removal of frame to final control.

\section{RESULTS}

The average treatment period of the patients was 21.6 weeks (range; 18 to 31 weeks). Lengthening was performed in 11 feet and two tibias. The lengthenings for the tibias were 4 and 3 centimeters, while they were $3 \mathrm{~cm}$ in five feet, $2 \mathrm{~cm}$ in four feet and $1 \mathrm{~cm}$ for two feet. No dermonecrosis or sensory or motor problems developed in the patients.

With the exception of one patient who had undergone arthrodesis, all of the patients had full range of knee and hip motion. Although all the patients were prescribed ankle movement exercises in the post-plaster period, the movements remained between 10 degree to 20 degree. Slight pin tract infections were found in eight feet. However, they were not serious enough to justify the prescription of antibiotics, and the problem was solved through dressings. Two patients developed a deep pin tract infection in the post-discharge period that lasted two months despite antibiotics and dressing treatment. A premature consolidation developed during treatment in one patient. This patient was followed up with reverse boot. Although the correction was not at the desired level, the treatment was continued until the foot became plantigrade. 


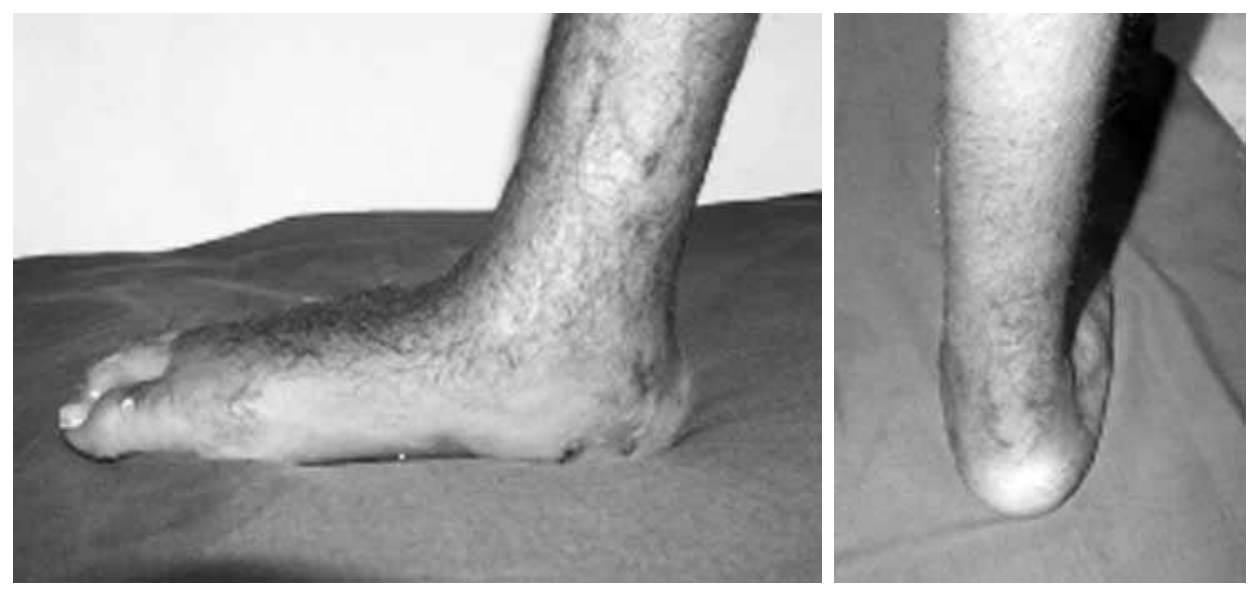

Figure 3. Plantigrade foot after correction (dorsal, medial and posterior view).

Another patient reported pain during the $20^{\text {th }}$ month control. The pain increased with walking and working, but did not prevent daily activities. The pain being at the metatarsal heads, examination revealed that the fat pad had thinned at this area and a silicone sole was prescribed. The complaints were found to have significantly decreased in the postoperative $35^{\text {th }}$ month control.

When the complications were evaluated, it was seen that two patients had deep infection; five had persistent metatarsus adductus; eight others had superficial pin tract infections; four had toe flexion contracture corrected by traction and one had a temporary neurovascular threat; as minor complications.

According to Paley's criteria, ${ }^{[8]}$ all the patients walked better after the treatment, and 25 feet were evaluated as plantigrade and two as non-plantigrade. Two patients developed pain complaints. Under this evaluation, the success rate of the treatment was $86.2 \%$.

\section{DISCUSSION}

Management of extremity deformities is still a challenge for most orthopaedic surgeons. ${ }^{[1-13,15]}$ A satisfactory correction of the deformed foot is independent from the method itself or surgeon's experience and depends rather on the differentiation of normal and abnormal foot and on the definition of various components of the deformities, including but not limited to length, angulation, translation and rotation in a systematic manner. ${ }^{[4]}$

Treatment of complicated and severe deformities becomes more radical as time advances and response to treatment becomes more difficult. ${ }^{[10]}$ Such radical interventions as triple arthrodesis, talectomy and even amputation are included. All these methods are technically difficult and prone to such complications as dermal necroses, pseudoarthroses, infections and vascular damage. The main purpose of these operations is to have a plantigrade lower extremity with equal heights on walls of the hindfoot (Figure 3).

The Ilizarov external fixator is suitable for the management of the correction and fixation of foot deformities by its very three-dimensional nature. ${ }^{[14,16,17]}$ The Ilizarov method permits the stepwise correction of all components of deformities without further shortening of osseous structures of the foot. The adaptation of bones and soft tissues to these mechanical forces are indeed striking. Ilizarov explains this with his tension-stress method built from his basic and clinical studies. ${ }^{[1,9,10,12,14,16,17]}$ The process leading to the biological plasticity is the stepwise correction. ${ }^{[1,6-10,13]}$

A slight overcorrection is recommended after the deformity correction is finalized, which may be achieved by good preoperative planning. The importance of this overcorrection was clearly understood in this study since the deformity relapsed to some extent as a result of the changes in the soft tissues after treatment. In cases where overcorrection is not made, a certain amount of deformity continues although the results are acceptable..$^{[1,9,10]}$

The second method is the deformity by distraction in the post-osteotomy period. In the patients over eight years of age, osteotomy is indicated if there is a fixed bone deformity and the joints are not congruent. Another indication is the case where there is a neuromuscular imbalance and the correction may not be perpetuated by tendon transfer or tenodesis. Osteotomy must definitely be performed if there is a previous fusion or a failure of healing. Finally, in the 
cases where the contracture is rather hard, osteotomic distraction is recommended instead of soft tissue procedure. ${ }^{[1,5-14,17]}$

Osteotomy was performed on nine patients because a triple arthrodesis was previously performed on three cases and all the patients were within the age range of 13 to 24 years. Distraction was the method of correction for the deformities of the other patients whose ages ranged between five and nine years. ${ }^{[1,79,10,14]}$

The complication rates are reported to be high in the treatments by external fixators. ${ }^{[1,9,10,18-20]}$ This is due to the fact that the Ilizarov external fixator is not well known and that the minor complications are frequent. For example, the pin tract infection is a serious problem. The minor complications always improve with good patient care. We had very rare pin tract infections in our cases.

It may be contended in conclusion that the Ilizarov method appears to be an efficient approach because of the three-dimensional characteristics of the foot and the fixator. Combining the procedure with an osteotomy depends on age and deformity characteristics. The Ilizarov external fixator yields simpler and satisfactory results compared to those of the biological plasticity and distraction osteogenesis. We believe that the Ilizarov method is highly successful in the correction of complicated foot deformities.

\section{Declaration of conflicting interests}

The authors declared no conflicts of interest with respect to the authorship and/or publication of this article.

\section{Funding}

The authors received no financial support for the research and/or authorship of this article.

\section{REFERENCES}

1. Kocaoğlu M, Eralp L, Atalar AC, Bilen FE. Correction of complex foot deformities using the Ilizarov external fixator. J Foot Ankle Surg 2002;41:30-9.

2. Karakurt L, Yılmaz E, Ayhan Ö, Yekeler H, Yahşi S, Serin E. Soft tissue contractures in clubfoot: An immunohistochemical study. Eklem Hastalik Cerrahisi 2004;15:26-30.

3. Bradish CF, Noor $\mathrm{S}$. The Ilizarov method in the management of relapsed club feet. J Bone Joint Surg [Br] 2000;82:387-91.

4. Cummings RJ, Lovell WW. Operative treatment of congenital idiopathic club foot. J Bone Joint Surg [Am] 1988;70:1108-12.

5. de la Huerta F. Correction of the neglected clubfoot by the Ilizarov method. Clin Orthop Relat Res 1994;301:89-93.

6. Grant $\mathrm{AD}$, Atar D, Lehman WB. Ilizarov technique in correction of foot deformities: a preliminary report. Foot Ankle 1990;11:1-5.

7. Grill F, Franke J. The Ilizarov distractor for the correction of relapsed or neglected clubfoot. J Bone Joint Surg [Br] 1987;69:593-7.

8. Herold HZ, Torok G. Surgical correction of neglected club foot in the older child and adult. J Bone Joint Surg [Am] 1973;55:1385-95.

9. Paley D. The correction of complex foot deformities using Ilizarov's distraction osteotomies. Clin Orthop Relat Res 1993;97-111.

10. Velazquez RJ, Bell DF, Armstrong PF, Babyn P, Tibshirani R. Complications of use of the Ilizarov technique in the correction of limb deformities in children. J Bone Joint Surg [Am] 1993;75:1148-56.

11. Kalenderer Ö, Ağuş H, Vatansever A, Özlük S, Şentürk H. Evaluation of structural changes in tarsal bones following complete subtalar release for congenital clubfoot. Eklem Hastalik Cerrahisi 2005;16:31-5.

12. Wallander H, Hansson G, Tjernström B. Correction of persistent clubfoot deformities with the Ilizarov external fixator. Experience in 10 previously operated feet followed for 2-5 years. Acta Orthop Scand 1996;67:283-7.

13. Franke J, Grill F, Hein G, Simon M. Correction of clubfoot relapse using Ilizarov's apparatus in children 8-15 years old. Arch Orthop Trauma Surg 1990;110:33-7.

14. Green SA, editor. Transosseous osteosynthesis. Berlin Heidelberg: Springer-Verlag; 1992.

15. Bell DF, Boyer MI, Armstrong PF. The use of the Ilizarov technique in the correction of limb deformities associated with skeletal dysplasia. J Pediatr Orthop 1992;12:283-90.

16. Ilizarov GA. Clinical application of the tension-stress effect for limb lengthening. Clin Orthop Relat Res 1990;250:8-26.

17. Karapınar H, Akgün U, Kazımoğlu C, Bulut T, Sener M. Ilizarov augmentation in the treatment of humeral shaft nonunions developing after failed intramedullary nailing. [Article in Turkish] Eklem Hastalik Cerrahisi 2010;21:142-6.

18. Serin E, Yılmaz E, Sarıkaya M, Sadioglu M, Pin tract infection after the use of Ilizarov type circular external fixator. Eklem Hastalik Cerrahisi 1998;9:109-14.

19. Fadel M, Versalitily of Ilizarov external fixator in managment of foot and ankle deformity, J Orthopaed Trauma 2005;6:63-8.

20. Kucukkaya M, Kabukcuoglu Y, Kuzgun U. Management of the neuromuscular foot deformities with the Ilizarov method. Foot Ankle Int 2002;23:135-41. 